2016, N 2

DOI: $10.1515 / 1 \mathrm{pts}-2016-0009$

\title{
TIME AND FREQUENCY SYNCHRONIZATION ON THE VIRAC RADIO TELESCOPE RT-32
}

\author{
V. Bezrukovs \\ Engineering Research Institute "Ventspils International \\ Radio Astronomy Centre” of Ventspils University College (VIRAC) \\ 101 Inzenieru Str., Ventspils, LV-3601, LATVIA \\ vladislavsb@venta.lv
}

\begin{abstract}
One of the main research directions of Ventspils International Radio Astronomy Centre (VIRAC) is radio astronomy and astrophysics. The instrumental base for the centre comprised two fully steerable parabolic antennas, RT-16 and RT-32 (i.e. with the mirror diameter of $16 \mathrm{~m}$ and $32 \mathrm{~m}$ ). After long reconstruction, radio telescope RT-32 is currently equipped with the receiving and data acquisition systems that allow observing in a wide frequency range from $327 \mathrm{MHz}$ to $9 \mathrm{GHz}$. New Antenna Control Unit (ACU) allows stable, fast and precise pointing of antenna. Time and frequency distribution service provide 5, 10 and $100 \mathrm{MHz}$ reference frequency, 1PPS signals and precise time stamps by NTP protocol and in the IRIG-B format by coaxial cable.

For the radio astronomical observations, main requirement of spatially Very Long Base Line Interferometric (VLBI) observations for the observatory is precise synchronization of the received and sampled data and linking to the exact time stamps. During October 2015, radio telescope RT-32 performance was tested in several successful VLBI experiments. The obtained results confirm the efficiency of the chosen methods of synchronization and the ability to reproduce them on similar antennas.
\end{abstract}

Keywords: radio telescope, antenna control system, time and frequency synchronization

\section{INTRODUCTION}

One of the main research directions of Ventspils International Radio Astronomy Centre (VIRAC) is radio astronomy and astrophysics. The instrumental base for the centre comprised two fully steerable parabolic antennas, RT-16 and RT-32 (i.e. with the mirror diameter of $16 \mathrm{~m}$ and $32 \mathrm{~m}$ ). The telescopes were built in the $60 \mathrm{~s}$ of the last century and used for military purposes. The reconstruction and instrumental refurbishment carried out for last years by VIRAC engineering team and various Latvian and international contractors made it possible to use these radio telescopes for the international scale fundamental and applied research in the field of radio 
astronomy. The most important aspect of the work is participation of RT-32 in the VLBI (Very Long Baseline Interferometry) international experiments. To use radio telescope RT-32 as a stable and reliable VLBI station it must comply with several performance criteria: fast, stable and precise pointing and tracking, receiver and data acquisition system compatible with VLBI standards and properly organised synchronization of all components.

\section{SCHEMATIC DIAGRAM OF THE RADIO TELESCOPE RT-32}

Operation of the radio telescope depends on the smooth and coordinated operation of various internal systems. Overall, schematic diagram of radio telescope RT-32 components is presented in Fig 1. Conventionally, a radio telescope operation can be divided into the following groups:

- Systems intended for the registration of a radio signal, digitizing the data and writing them on the media.

- Antenna Motion Control Systems, including monitoring and control of motors, the calculation of antenna pointing and movement trajectories generation, controlling of antenna position ad status sensors.

- Secondary systems for the monitoring of the weather situation, logging of antenna status, recorded data quality and other.

- However, for the successful functioning of a radio telescope as an instrument able to solve scientific and applied goals, a stable and highly accurate synchronization of all systems is needed. For these purposes, on the RT-32 time and frequency distribution service are used.

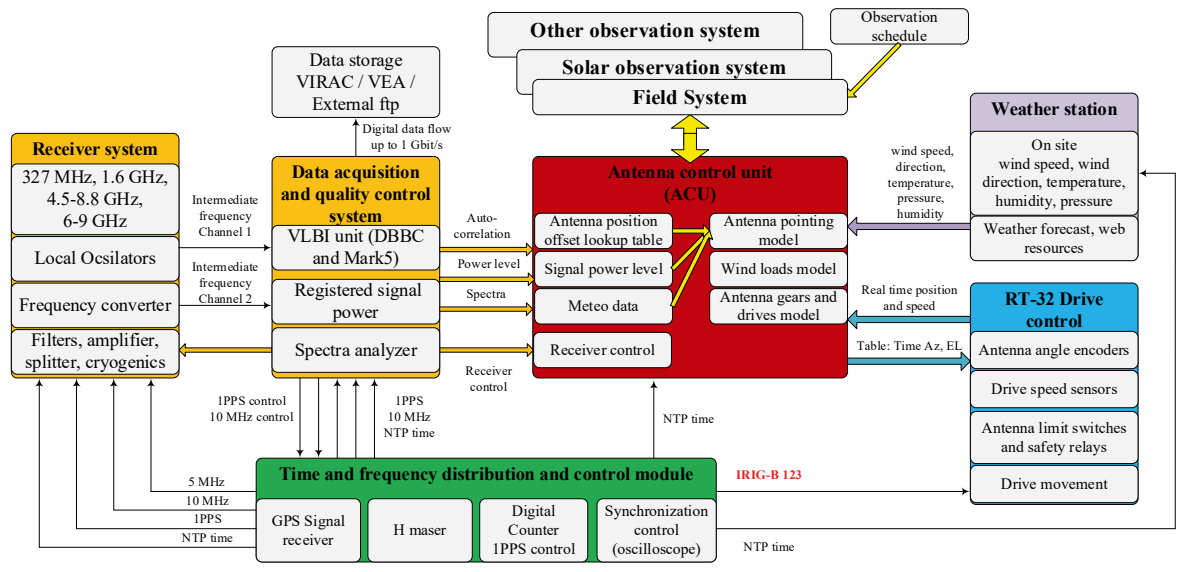

Fig. 1. Schematic diagram of systems incorporated in the radio telescope RT-32.

\section{TIME AND FREQUENCY DISTRIBUTION AND CONTROL SERVICES}

For the radio astronomical observations, the main requirement of spatially Very Long Base Line Interferometric (VLBI) observations for the observatory is precise synchronization of the received and sampled data and linking to the exact time 
stamps. Precise time is also needed for accurate calculations of current coordinates of the antenna and the observed objects. As the frequency and time standard for RT-32 an active hydrogen maser Quartz CH1-75A is used, which generates reference frequencies of 5, $10100 \mathrm{MHz}$ and 1PPS signal. 5 and $10 \mathrm{MHz}$ reference frequency are required for radio telescope receiver units, enabling stable work of their Local Oscillators. Additionally, $10 \mathrm{MHz}$ sinusoidal reference signal is supplied to the radio telescope digital backbends (DBBC and TN-6) and ensures coherent data digitalization.

For the setting and checking the time scale "Symmetricom XL-GPS Time and Frequency" system is employed. This GPS receiver generates one-second pulses based on the signals from GPS satellites. In addition, it has an NTP-server providing accurate time transfer to all devices of the telescope via a LAN (Local Area Network).

To control the synchronization of the observatory acquisition systems, a fourchannel oscilloscope R\&S RTO 1014 is applied, which displays the PPS signals from GPS, DBBC, Mk5b, $10 \mathrm{MHz}$ from DBBC and $10 \mathrm{MHz}$ from hydrogen frequency and time standard. In the case when one of the devices loses synchronization, this will be easily detected on the oscilloscope's display.

For long-term control of active hydrogen maser Quartz CH1-75A performance and stability, 1PPS signal from CH1-75A and 1PPS signal from GPS receiver are connected to the digital counter Agilent 53132A, which calculates difference between these signals. Digital counter sends this data to the observatory server by GPIB-Ethernet interface.

\section{RECEIVING AND DATA ACQUISITION SYSTEMS OF RADIO TELESCOPE RT-32}

Selection of receiving systems is determined by scientific and applied tasks, which are topical for VIRAC observatory. At present, VIRAC works in the following directions:

- investigation into the motion parameters of objects in the near-Earth space (space debris, satellites, asteroids) and planets;

- studying the Earth's ionosphere;

- studying the solar radio emission;

- observations in the international VLBI-networks, including the European VLBI network (EVN).

To achieve these objectives, it is possible to use the following receiving systems:

- $\quad 327 \mathrm{MHz}$ (92 cm, P band) - primary focus, VLBI;

- $1.6 \mathrm{GHz}$ (18 cm, L band) - secondary focus, GNSS satellites tracking, VLBI;

- $\quad 4.5-8.8 \mathrm{GHz}$ (6 cm; C, M, X bands) - secondary focus, VLBI, space debris radio location;

- $\quad 6.9-9.3 \mathrm{GHz}(3.7-4.2 \mathrm{~cm})$ - secondary focus, solar spectro-polarimetric studies [1], [2]. 
For the receivers $327 \mathrm{MHz}$ and $4.5-8.8 \mathrm{GHz}$ the signal generator Rohde\&Schwarz (R\&S) SMP 04 is used as the Local Oscillator (LO) synchronized by a hydrogen frequency standard.

For digitalization and registration of the received signal, at the RT-32 two independent systems are used: TN-16 - the NIRFI terminal for signal record with a sampling frequency up to $16 \mathrm{MHz}$ (developed at the Radiophysical Research Institute, Nizhny Novgorod) and DBBC - the Digital Base Band Converter (developed in the last decade at the Institute of Radioastronomy, Noto) as a generic, modular radio-astronomical data acquisition architecture to be used inside the European VLBI community [3].

The signals applied at the inputs of TN-16: the analogue input signal, clock signal (up to $16 \mathrm{MHz}$ ), 1PPS (pulse-per-second) reference signal from the hydrogen frequency standard and $5 \mathrm{~V}$ from a DC voltage.

The DBBC unit is composed of a base box (containing power supply, control computer, clock distribution and JTAG interface), and a stack of small modular boards, which can be composed according to the user needs. The first and the last modules in the system (FILA boards) provide the control signal distribution, a DAC for monitoring, and the electric interface to the standard VSI bus to the VLBI data recorder. The digitized signal is fed to Mk5b by VSI-H interface. For its operation, DBBC requires the following input signals: $10 \mathrm{MHz}$ reference and 1PPS (supplied by a hydrogen frequency standard). For control of the input signal, the internal synchronization and sampled band DBBC are fitted with the following outputs: "RF out" and "RF monitor" for each of the four Conditioning Modules, "1 PPS out", "10 $\mathrm{MHz}$ out" and "AnalogOut", which allow checking all sampled channels.

The system Mk5b (connected to DBBC through VSI-H cable) is used for recording the sampled data flow. For synchronization, Mk5b uses $1 \mathrm{PPS}$ and $32 \mathrm{MHz}$ signals obtained through VSI-H interface from the DBBC [1], [2], [3].

\section{ANTENNA MOTION CONTROL SYSTEMS}

In the radio telescopes RT-32 and RT-16 for the antenna motion control, the Antenna Control Unit (ACU) developed by MT Mechatronics Company is used.

The purpose of the ACU is to provide a high quality stable tracking behaviour enabling the scientist to track star objects, the sun or satellites. New ACU system was installed during refurbishment of these radio telescopes, which was finished at the end of summer 2015. The old motors and drive system were replaced, and telescopes were equipped with a new servo system. At present, the telescope axes are controlled by the ACU, which consists of several modules and interfaces.

The software comprises the following basic parts:

- Facility Control Module: Temperature Sensors, Safety System, Fieldbus and Power Status;

- HMI Module: Handling of HMI interfaces;

- Axis Module: Trajectory Generator, Axis Command Handling, Axis State Machine; 
- Pointing and Tracking Module: Program Tracking, TLE Tracking, Time System.

External Interfaces to the software are:

- The EtherCAT Field Bus controller that communicates with all drive system components, e.g. motor modules, encoder systems, serial interfaces and MTM clock module.

- The TcpIp Interface that handles the communication with different HMI visualizations and radio telescope remote connection.

- Beckhoff ADS internal connection that is used for diagnosis, logging and debugging [4].

The ACU module is integrated in the radio telescope control system (RT-Control), which coordinates work of all radio telescope components. One of the major parts of RT-Control is a Field System (FS) - software unit developed by NASA. The FS control while the observational process: defines targets for ACU, sets working frequencies in the $\mathrm{DBBC}$, sets recording time and mode in the $\mathrm{Mk} 5$, additionally records weather conditions received from a local meteorological station. As all mentioned units should work synchronously, correctly organised time synchronization is of particular importance. In the VIRAC observatory, time signals are distributed from a local NTP timeserver. In the Windows based computers, NTP time is set by "SP TymeSync" software package written by Alexander Panchenko. In turn, Linux machines use their own NTP daemons.

In addition, to provide reliability, ACU obtains time directly from a GPS receiver using IRIG-B 123 standard format for transferring timing information by coaxial cable.

\section{CONCLUSIONS}

After long reconstruction, the radio telescope RT-32 is currently equipped with the receiving and data acquisition systems that allow observing in a wide frequency range from $327 \mathrm{MHz}$ to $9 \mathrm{GHz}$. New ACU allows stable, fast and precise pointing of antenna. Time and frequency distribution service provides 5, 10 and 100 $\mathrm{MHz}$ reference frequency, 1 PPS signals and price time stamps by the NTP server and in the IRIG-B format by coaxial cable.

During October 2015, the performance of radio telescope RT-32 was tested in several successful experiments: GNSS satellite tracking tests; VLBI observations in frequency bands of 1.6, 5, 6.7 and $8 \mathrm{GHz}$ in collaboration with EVN network; VLBI observations of GNSS satellites at $1.6 \mathrm{GHz}$ in collaboration with the Radiophysical Research Institute, Nizhny Novgorod.

The obtained results confirm the efficiency of the chosen methods of synchronization and can be reproduced on similar antennas.

\section{ACKNOWLEDGEMENTS}

The present research has been conducted as part of research project No. L-KC-11-0006 funded by the European Regional Development Fund. The project 
is implemented by Ltd. "ORAM Mobile" in collaboration with Ventspils University College. The author would like to express his gratitude to VIRAC engineering and research team for their hard work devoted to radio telescope reconstruction as well as to MT Mechatronics team.

\title{
REFERENCES
}

1. Bezrukovs, V., Shmeld, I., Nechaeva, M., Trokss, J., Bezrukovs, D., Klapers, M., Berzins, A., and Lesins, A. (2012). Receiving and data acquisition systems of RT-32 for VLBI observations. Latvian Journal of Physics and Technical Sciences 6 (2), 30-42.

2. Bezrukovs, D. (2013). Spectral polarimetric observations of the Sun by VIRAC RT-32 radiotelescope. Baltic Astronomy 22 (1).

3. Tuccari, G., Alef, W., Bertarini, A., Buttaccio, S., Comoretto, G., Graham, D., Meidhart, A., Platania, P., Russo, A., Roy, A., Wunderlich, M., Zeithoefler, R., and Xiang, Y. (2010). DBBC2 backend: Status and development plan. In: IVS General Meeting Proceedings.

4. Petersen, A., Hartmann, S., and Tschetschel R. (2015). Ventspils RT-16 / RT-32 Servo. Operational Manual. VTP2-DOC-34100-01.

\section{VSRC RADIO TELESKOPA RT-32 LAIKA UN FREKVENCES SINHRONIZĀCIJA}

\author{
V. Bezrukovs
}

Kopsavilkums

Viens no Ventspils Starptautiskā Radio Astronomijas Centra (VSRC) galvenajiem darbības virzieniem ir radio astronomija un astrofizika. VSRC instrumentālo bāzi veido divas pilnīgi grozāmas paraboliskas antenas RT-16 un RT-32 (ar spoguḷa diametriem 16 m un $32 \mathrm{~m}$ ). Pēc ilgas rekonstrukcijas, radioteleskops RT-32 šobrīd ir aprīkots ar uztveršanas un datu reǵistrācijas sistēmu, kas ḷauj veikt novērojumus plašā frekvenču diapazonā no $327 \mathrm{MHz}$ līdz $9 \mathrm{GHz}$. Jauna antenas vadības sistēma (ACU) ļauj nodrošināt stabilu, ātru un precīzu antenas uzvadīšanu un sekošanu. Laika un frekvences dienests antenas mezgliem nodrošina 5, 10 un $100 \mathrm{MHz}$ referenču signālus, vienas sekundes (1PPS) impulsus un precīzus laika mārkerus ar NTP protokolu un IRIG-B formātu caur koaksiālo kabeli.

Radio astronomiskajiem novērojumiem, īpaši lielas bāzes interferometriskiem (VLBI) novērojumiem, galvenā prasība ir reǵistrēto signālu un nociparoto datu sinhronizācija un nodrošināšana ar precīziem laika mārkeriem.

No 2015. gada oktobra radio teleskopa RT-32 veiktspēja tika pārbaudīta vairākos veiksmīgos starptautiskos VLBI eksperimentos. Iegūtie rezultāti apstiprina izvēlēto sinhronizācijas metožu efektivitāti un iespēju reproducēt tos uz līdzīgām antenām.

02.11.2015. 